\title{
Kinematika dan Antarmuka Robot SCARA Serpent
}

\author{
AFRIZAL MAYUB ${ }^{1}$, IVAN SYAHRONI ${ }^{2}$, FAHMIZAL ${ }^{2}$, MUHAMMAD ARROFIQ ${ }^{2}$ \\ ${ }^{1}$ Pascasarjana S2 Pendidikan IPA FKIP, Universitas Bengkulu, Indonesia \\ ${ }^{2}$ Teknik Elektro dan Informatika Sekolah Vokasi Universitas Gadjah Mada, Indonesia \\ Email: afrizalmayub@unib.ac.id
}

Received 24 Maret 2020 | Revised 14 April 2020 | Accepted 29 April 2020

\begin{abstract}
ABSTRAK
Penelitian ini menyajikan kendali pergerakan posisi dari robot SCARA Serpent menggunakan persamaan kinematika dan antarmuka berbasis Processing IDE. Antarmuka bertujuan untuk memudahkan dalam pengendalian robot SCARA Serpent dan mendapatkan data koordinat objek. Data ini digunakan sebagai masukan persamaan kinematika balik untuk menentukan besar sudut tiap joint. Untuk mendapatkan hasil pergerakan robot SCARA Serpent yang baik, kendali Proporsional, Integral, Differensial (PID) diterapkan dalam mengendalikan posisi setiap joint-nya. Pada pengujian, robot SCARA Serpent diuiji dengan tiga pengujian, yaitu pengujian sudut joint, pengujian koordinat end-effector, dan pengujian kendali PID. Dari hasil pengujian, sistem dapat berjalan dengan baik. Hasil parameter kendali PID diperoleh dengan tuning secara eksperimental dengan parameter $K p=5.5, K i=0.001$ dan $K d=10$ untuk sudut joint shoulder pada robot SCARA Serpent menuju error steady state bernilai nol.
\end{abstract}

Kata kunci: SCARA Serpent, Kinematika, Antarmuka, Kendali PID.

\begin{abstract}
This paper presents position control of the SCARA Serpent robot using kinematics equations and Processing IDE-based interfaces. The interface aims to make it easier in controlling the SCARA Serpent robot and to get object coordinate data. This data are used as input to the reverse kinematics equation to determine the angle of each joint. To get good SCARA Serpent robot movement results, Proportional, Integral, Differential (PID) control is applied in controlling the position of each joint. In the testing, the SCARA Serpent robot is tested with three tests, namely joint angle testing, end-effector coordinate testing, and PID control testing. From the test results, the system can run well. The results of the PID control parameters were obtained by experimental tuning with parameters $K p=5.5, K i=$ 0.001 and $K d=10$ for the joint shoulder angle of the SCARA Serpent robot towards zero steady state error.
\end{abstract}

Keywords: SCARA Serpent, Kinematics, Interface, PID Controller. 
Mayub, dkk

\section{PENDAHULUAN}

Perkembangan teknologi serta ilmu pengetahuan dari masa ke masa semakin berkembang. Perkembangan ini berjalan seiring dengan penelitian-penelitian di berbagai disiplin ilmu khususnya dalam bidang otomasi. Hal ini dapat dilihat dari banyaknya penggunaan sistem otomasi dalam dunia industri seperti penggunaan robot dalam menyelesaikan pekerjaan manusia. Untuk itu, perancangan robot merupakan salah satu solusi dalam memenuhi tuntutan dan membantu kebutuhan manusia (Faris, dkk, 2012).

Pemilihan robot untuk menggantikan pekerjaan manusia tidak terlepas dengan berbagai kelebihannya. Salah satu kelebihannya, robot dapat melakukan suatu pekerjaan yang sama dan berulang tanpa merasakan lelah seperti halnya manusia. Pekerjaan ini dapat ditemukan dalam bidang industri khususnya pada bagian produksi. Robot dengan sistem lengan (robot arm system) merupakan salah satu jenis robot yang dominan berada dalam bidang industri (Bimantaka \& Harjoko, 2014).

Selective Compilance Assembly Robot Arm atau biasa dikenal dengan robot SCARA merupakan salah satu jenis dari robot lengan yang umumnya sering digunakan di dalam dunia industri (Mandal, 2016). Robot SCARA terdiri dari base, lengan shoulder, lengan elbow dan endeffector. Posisi end-effector pada robot SCARA berada pada sebuah koordinat kartesian $(x, y)$. Pengembangan dari robot lengan saat ini telah berkembang pesat. Beberapa robot lengan memiliki beberapa fitur kecerdasan seperti ditambahkannya sebuah kamera sehingga pergerakan dari robot bergantung pada warna atau bentuk dari setiap objek (Vijayalaxmi, dkk, 2013).

Robot SCARA memiliki banyak jenis, robot SCARA Serpent merupakan jenis yang dibahas pada penelitian ini. Robot SCARA Serpent didesain oleh Richard Becker pada pertengahan tahun 1980 setelah keluar dari perusahaan lamanya. Richard kemudian mendirikan sebuah perusahaan dengan nama "Cybernetic Applications" yang merupakan perusahaan pada bidang robot manufaktur (Fazakerley \& BeebControl, 2018). Robot SCARA Serpent dirancang untuk memindahkan sebuah objek menuju titik koordinat yang sudah ditentukan. Untuk mencapai sebuah koordinat, sebuah robot memerlukan sebuah perhitungan kinematika balik yang membuat titik koordinat tersebut dapat diubah menjadi sebuah nilai sudut untuk setiap joint-nya. Setiap joint pada robot nantinya bergerak sesuai dengan besaran sudut joint yang sudah ditentukan (Setiawan, dkk, 2015). Untuk mendapatkan sebuah respon, umumnya setiap robot mempunyai sebuah sistem umpan balik yang berfungsi untuk membandingkan nilai yang terukur dengan nilai yang ditentukan. Pada robot SCARA Serpent, umpan balik menggunakan sensor potensiometer yang diletakkan pada setiap joint pada robot (Az Uchrowi, dkk, 2019).

Penelitian terkait robot SCARA telah banyak dilakukan oleh beberapa peneliti seperti pada (Shariatee, dkk, 2014). Pada makalah ini peneliti merancang sebuah desain robot SCARA yang memiliki spesifikasi sejajar dengan robot industri pada negaranya, Iran. Peneliti merancang desain mekanik, elektronik, sistem kontrol dengan biaya seminimal mungkin. Robot SCARA tersebut menggunakan kontrol kendali PID, dengan tingkat kesalahan yang kecil serta dapat menghasilkan pergerakan dengan tingkat presisi kurang lebih $0.01 \mathrm{~mm}$ dan melakukan pergerakan $8.5 \mathrm{~m} / \mathrm{s}$ pada bidang $\mathrm{xy}$.

Berbeda dengan makalah pada (Zhang \& Zhang, 2019) yang melakukan simulasi robot SCARA menggunakan SimMechanics yang terdapat pada aplikasi Matlab. Simulasi yang dilakukan peneliti meliputi dari pergerakan kinematika maju yang dilakukan menggunakan parameter $\mathrm{DH}$. SimMechanics pada penelitian tersebut digunakan untuk merancang diagram 
blok dari sistem serta menyimulasikan untuk mengubah perpindahan, kecepatan, dan akselerasi dari setiap joint. Selain itu, Robot SCARA dapat dikembangkan lebih jauh seperti yang dilakukan pada (Pillajo \& Sierra, 2013). Pada makalah ini, peneliti menambahkan sebuah sensor Kinect untuk merekam pergerakan dari sebuah tangan. Robot SCARA pada makalah ini, melakukan pergerakan sesuai dengan pergerakan tangan secara langsung. $\mathrm{Hal}$ ini menunjukkan bahwa, robot SCARA dapat dikembangkan beraneka ragam.

Sedangkan pada makalah ini, disajikan kendali pergerakan posisi dari robot SCARA Serpent menggunakan persamaan kinematika dan antarmuka berbasis Processing IDE. Antarmuka bertujuan untuk memudahkan dalam mengendalikan robot SCARA Serpent dan mendapatkan data koordinat objek. Selain itu, implementasi Kendali PID digunakan untuk membuat pergerakan menjadi stabil dan membuat posisi dari end-effector dari robot SCARA Serpent menjadi lebih cepat dan tepat saat menuju titik yang telah ditentukan. Susunan pada makalah ini disusun menjadi empat bagian. Pada bagian 2 perancangan kinematika dan antarmuka Robot SCARA Serpent dijelaskan. Prosedur pengujian dan pembahasan sistem disajikan di bagian 3 beserta data eksperimen. Dan bagian 4 adalah kesimpulan dari makalah ini.

\section{PERANCANGAN SISTEM}

\subsection{Kinematika}

Kinematika pada robot lengan SCARA Serpent terbagi menjadi dua jenis yaitu kinematika balik (inverse kinematic) dan kinematika maju (forward kinematic). Kinematika balik digunakan untuk mendapatkan nilai sudut pada setiap joint jika diketahui posisi $(x, y)$. Sedangkan untuk kinematika maju digunakan untuk mendapatkan posisi $(x, y)$ jika diketahui besar nilai pada setiap joint (Prabantara \& Harjoko, 2013). Penjelasan terkait pergerakan kinematika dapat digambarkan melalui sebuah blog diagram yang ditunjukkan pada Gambar 1.

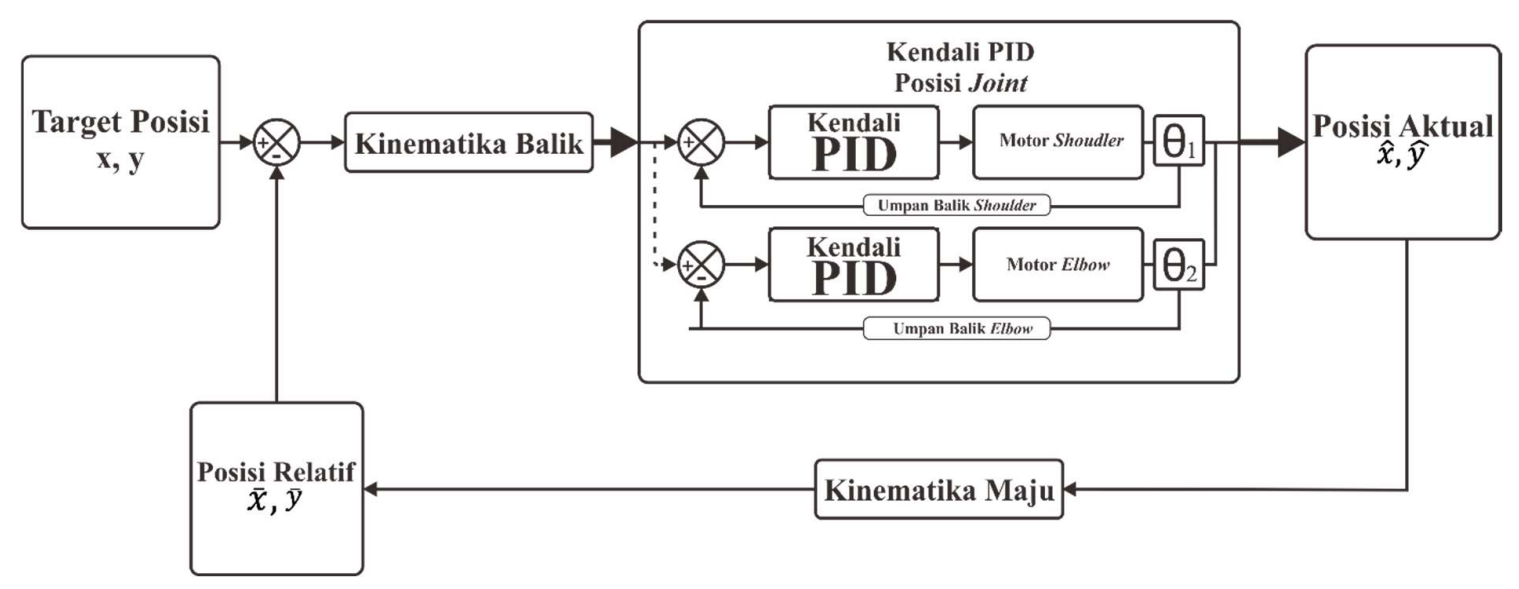

\section{Gambar 1. Blok Diagram Sistem Keseluruhan}

\subsubsection{Kinematika Maju}

Dalam kinematika maju terdapat beberapa metode untuk memudahkan dalam mencari sebuah posisi akhir. Salah satu metode yang umum digunakan adalah metode Denavit-Hartenberg (DH). Metode $\mathrm{DH}$ merupakan metode yang menggabungkan proses perhitungan rotasi dan translasi menjadi sebuah matriks dengan menyertakan nilai sudut putar dan jarak sendi dari sebuah lengan robot yang didapat dari konfigurasi pada setiap robot (Dharmawan \& Lina, 2017). 
Metode DH mempunyai empat buah aturan terkait penulisan dari matriks robot, empat aturan tersebut yaitu pertama, sumbu $z$ harus menjadi sumbu rotasi atau translasi dari sebuah joint. Kedua, sumbu $x$ harus tegak lurus dari sumbu $z$ frame sebelumnya. Ketiga, sumbu $x$ harus memotong atau menyilang dari sumbu $z$ frame sebelumnya. Keempat, sumbu $y$ harus digambarkan sesuai dengan aturan tangan kanan setelah sumbu $x$ dan sumbu $z$ setiap frame digambarkan. Gambar 2 merupakan struktur dari konfigurasi SCARA Serpent, sedangkan Tabel 1 merupakan spesifikasi robot SCARA Serpent dan Tabel 2 merupakan tabel konfigurasi DH robot SCARA Serpent.

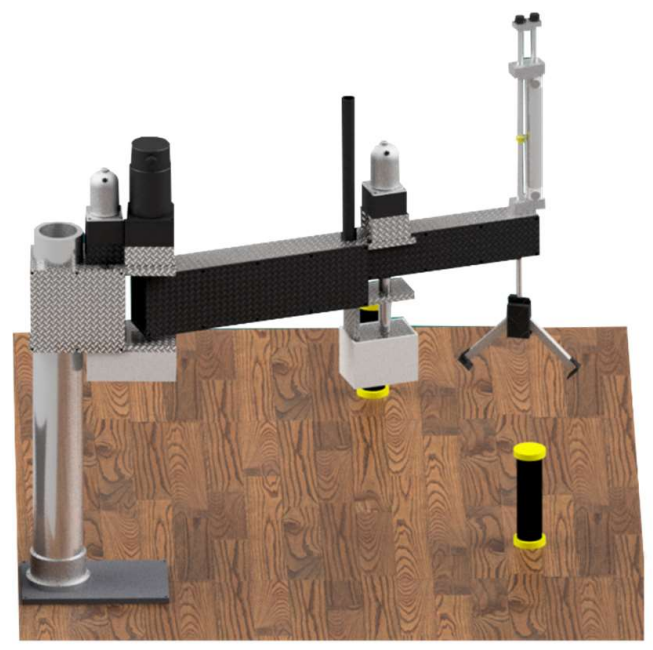

(a)

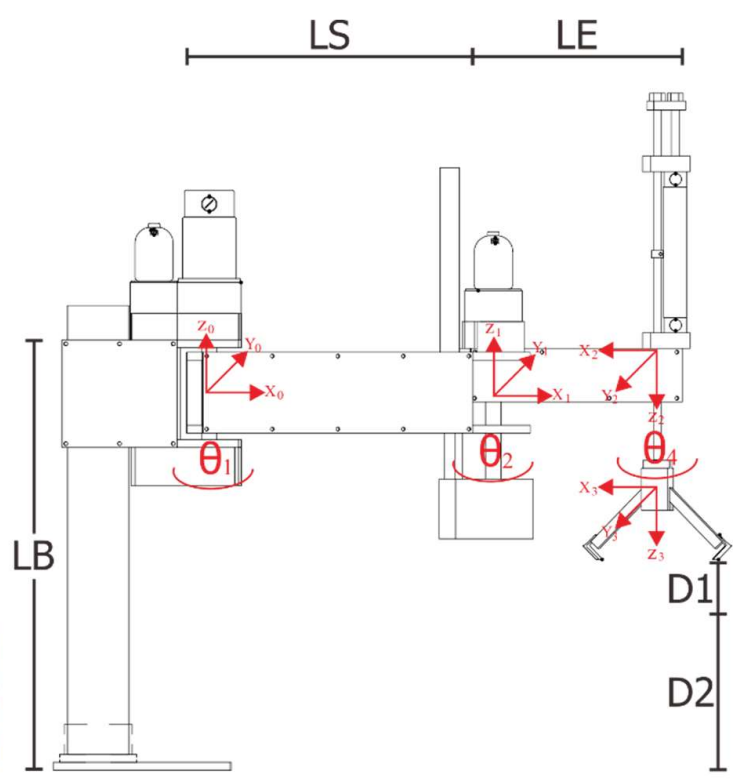

(b)

Gambar 2. (a) Bentuk Fisik Robot SCARA Serpent; (b) Konfigurasi Robot SCARA Serpent

Pada konfigurasi robot SCARA Serpent yang ditunjukkan pada Gambar 2 terdapat lengan shoulder (LS). Lengan shoulder berporos pada sebuah base yang memiliki tinggi $500 \mathrm{~mm}$. Lengan shoulder dalam pergerakannya akan membuat nilai sudut yang ditandai dengan $\theta_{1}$. Lengan elbow (LE) berporos pada ujung lengan shoulder yang pergerakannya membentuk sebuah sudut yang ditandai dengan $\theta_{2}$. Sedangkan untuk end-effector (D1) yang berporos pada ujung dari lengan elbowakan membentuk sebuah sudut yang ditandai dengan $\theta_{4}$. Selain itu, end-effector juga memiliki pergerakan secara vertikal, D1 merupakan jarak dari pergerakan end-effector dan D2 merupakan jarak end-effectordengan permukaan saat kondisi end-effector sedang dalam posisi awal.

Tabel 1. Spesifikasi Robot SCARA Serpent

\begin{tabular}{|l|c|}
\hline \multicolumn{1}{|c|}{ Keterangan } & Nilai \\
\hline Panjang lengan base (LB) & $500 \mathrm{~mm}$ \\
\hline Panjang lengan shoulder(LS) & $360 \mathrm{~mm}$ \\
\hline Panjang lengan elbow (LE) & $290 \mathrm{~mm}$ \\
\hline Pergerakan end-effector(D1) & $90 \mathrm{~mm}$ \\
\hline Jarak end-effector dengan permukaan (D2) & $250 \mathrm{~mm}$ \\
\hline
\end{tabular}


Tabel 2. Spesifikasi Robot SCARA Serpent

\begin{tabular}{|c|c|c|c|c|}
\hline Link & $\boldsymbol{a}_{\boldsymbol{i}}$ & $\boldsymbol{\alpha}_{\boldsymbol{i}}$ & $\boldsymbol{d}_{\boldsymbol{i}}$ & $\boldsymbol{\theta}_{\boldsymbol{i}}$ \\
\hline 1 & $\mathrm{LS}$ & 0 & 0 & $\theta_{1}$ \\
\hline 2 & $\mathrm{LE}$ & $\pi$ & 0 & $\theta_{2}$ \\
\hline 3 & 0 & 0 & $\mathrm{D} 1$ & 0 \\
\hline 4 & 0 & 0 & $\mathrm{D} 2$ & $\theta_{4}$ \\
\hline
\end{tabular}

Dari paramater DH yang ditunjukkan pada Tabel 2 maka didapatkan nilai untuk ditransformasikan ke dalam bentuk matriks DH seperti yang ditunjukkan pada Persamaan (1). Nantinya ke empat buah nilai yang dihasilkan oleh setiap joint digabungkan ke dalam satu bentuk matriks yang menghasilkan persamaan untuk mencari koordinat $x, y$,dan $z$. Selanjutnya panjang lengan shoulder(LS), lengan elbow (LE), dan panjang naik end-effector dimasukkan ke dalam persamaan tersebut.

$$
A_{i}=\left[\begin{array}{cccc}
\cos \theta_{i} & -\cos \alpha_{i} \sin \theta_{i} & \sin \alpha_{i} \sin \theta_{i} & a_{i} \cos \theta_{i} \\
\sin \theta_{i} & \cos \alpha_{i} \cos \theta_{i} & -\sin \alpha_{i} \cos \theta_{i} & a_{i} \sin \theta_{i} \\
0 & \sin \alpha_{i} & \cos \alpha_{i} & d_{i} \\
0 & 0 & 0 & 1
\end{array}\right]
$$

Keempat buah nilai dari setiap joint yang sudah ditransformasikan ke dalam bentuk matriks ditunjukkan pada Persamaan (2), (3), (4), (5). Keempat buah matriks tersebut kemudian digabungkan menjadi satu buah matriks seperti yang ditunjukkan pada Persamaan (6). $C$ direpresentasikan sebagai $\cos$ dan $S$ direpresentasikan sebagai $\sin$.

$$
\begin{aligned}
& A_{1}=\left[\begin{array}{cccc}
C_{1} & -S_{1} & 0 & a_{1} C_{1} \\
S_{1} & C_{1} & 0 & a_{1} S_{1} \\
0 & 0 & 1 & 0 \\
0 & 0 & 0 & 1
\end{array}\right] \\
& A_{2}=\left[\begin{array}{cccc}
C_{2} & S_{2} & 0 & a_{2} C_{2} \\
S_{2} & -C_{2} & 0 & a_{2} S_{2} \\
0 & 0 & -1 & 0 \\
0 & 0 & 0 & 1
\end{array}\right] \\
& A_{3}=\left[\begin{array}{cccc}
1 & 0 & 0 & 0 \\
0 & 1 & 0 & 0 \\
0 & 0 & 1 & d_{3} \\
0 & 0 & 0 & 1
\end{array}\right] \\
& A_{4}=\left[\begin{array}{cccc}
C_{4} & -S_{4} & 0 & 0 \\
S_{4} & C_{4} & 0 & 0 \\
0 & 0 & 1 & d_{4} \\
0 & 0 & 0 & 1
\end{array}\right] \\
& T_{4}^{0}=A_{1} \ldots A_{4}=\left[\begin{array}{cccc}
C_{12} C_{4} S_{12} S_{4} & -C_{12} S_{4}+S_{12} C_{4} & 0 & a_{1} C_{1}+a_{2} C_{12} \\
S_{12} C_{4}-C_{12} S_{4} & -S_{12} S_{4}-C_{12} C_{4} & 0 & a_{1} S_{1}+a_{2} S_{12} \\
0 & 0 & -1 & -d_{3}-d_{4} \\
0 & 0 & 0 & 1
\end{array}\right]
\end{aligned}
$$

Dengan menggunakan Persamaan (6) memungkinkan untuk menghitung nilai dari koordinat $x, y$ dan $z$. Nilai koordinat dari $x$ dapat ditentukan melalui Persamaan (7). Nilai koordinat $y$ dapat ditentukan melalui Persaamaan (8). Dan Nilai koordinat $z$ dapat ditentukan melalui Persamaan (9). 


$$
\begin{gathered}
x=a_{1} C_{1}+a_{2} C_{12} \\
y=a_{1} S_{1}+a_{2} S_{12} \\
z=-d_{3}-d_{4}
\end{gathered}
$$

\subsubsection{Kinematika Balik}

Kinematika balik merupakan perhitungan untuk mencari variabel sudut (joint) robot dalam menentukan posisi dan orientasi dari end-effector. Penyelesaian kinematika balik ini dapat diselesaikan dengan menggunakan hukum Pythagoras dan aturan cosinus. Penyelesaian kinematika dalam robot SCARA Serpent diselesaikan menggunakan satu sisi, yaitu sisi atas (top view) dari struktur robot lengan. Dengan begitu, nilai sudut joint shoulderdan sudut joint elbow dapat ditemukan (Oktama, dkk, 2018). Gambar 3 merupakan gambaran untuk mendapatkan sebuah persamaan untuk menghasilkan nilai sudut pada setiap joint.

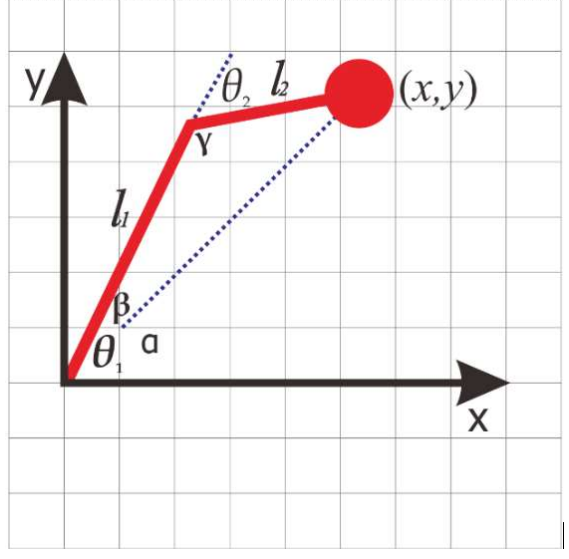

(a)

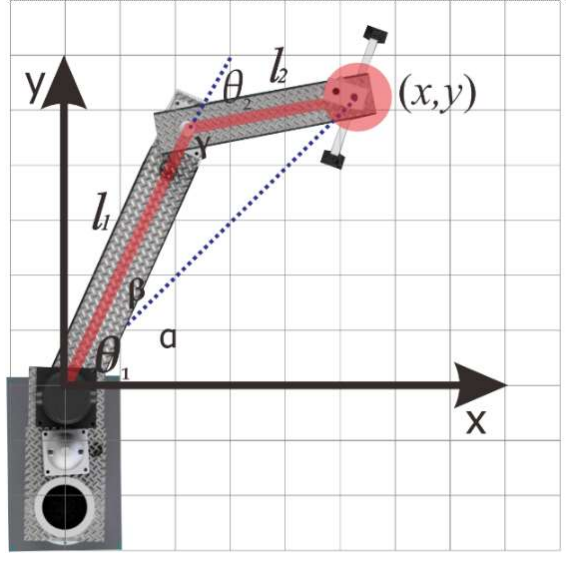

(b)

\section{Gambar 3. (a) Diagram Kartesian Robot SCARA Serpent; (b) Diagram Kartesian Tampak Atas Robot SCARA Serpent}

Dilihat pada Gambar $3, l_{1}$ merupakan panjang lengan shoulder dan $l_{2}$ merupakan panjang lengan dari elbow. $\theta_{1}$ merupakan sudut dari shoulder dan $\theta_{2}$ merupakan sudut dari elbow. Dengan menggunakan hukum cosinus, didapatkan sebuah persamaan seperti Persamaan (10). Pada Persamaan (10) terdapat fungsi cos yang dapat diubah sesuai dengan prinsip dari hukum cosinus menjadi seperti pada Persamaan (11).

$$
\begin{gathered}
\left(x^{2}+y^{2}\right)=l_{1}^{2}+l_{2}^{2}-2 l_{1}^{2} l_{2}^{2} \cos \left(180-\theta_{2}\right) \\
\left(x^{2}+y^{2}\right)=l_{1}^{2}+l_{2}^{2}-2 l_{1}^{2} l_{2}^{2} \cos \left(\theta_{2}\right)
\end{gathered}
$$

Inti dari perhitungan ini adalah mencari sebuah nilai dari $\theta_{2}$ maka jika dilihat dari Persamaan (11) untuk lebih memudahkannya, persamaan menjadi seperti pada Persamaan (12). Pada Persamaan (12), nilai dari $\theta_{2}$ dapat diketahui dengan melanjutkan persamaan menjadi seperti Persamaan (13). Nilai dari $\theta_{2}$ atau sudut dari elbow dapat diketahui dengan cara memasukkan nilai dari koordinat $x, y$ serta nilai dari $l_{1}$ dan $l_{2}$. Nilai $x, y$ merupakan posisi akhir dari endeffector. Sedangkan dalam menentukan sudut shoulder yang ditandai dengan simbol $\theta_{1}$ menggunakan persamaan cosinus yang dituliskan pada Persamaan (14).

$$
\cos \left(\theta_{2}\right)=\frac{x^{2}+y^{2}-l_{1}^{2}-l_{2}^{2}}{2 l_{1}^{2} l_{2}^{2}}
$$




$$
\begin{gathered}
\theta_{2}=\cos ^{-1}\left(\frac{x^{2}+y^{2}-l_{1}^{2}-l_{2}^{2}}{2 l_{1}^{2} l_{2}^{2}}\right) \\
\frac{\sin (\beta)}{l_{2}}=\frac{\sin (\gamma)}{\sqrt{x^{2}+y^{2}}} ; \alpha=\tan ^{-1}\left(\frac{y}{x}\right)
\end{gathered}
$$

Pada Persamaan (14) beberapa nilai dapat diubah sesuai dengan hukum cosinus seperti $\sin (\gamma)=\sin \left(180-\theta_{2}\right)=\sin \left(\theta_{2}\right)$ dengan mengubah $\sin (\gamma)$ menjadi $\sin \left(\theta_{2}\right)$ maka persamaan menjadi seperti yang ditunjukkan pada Persamaan (15). Jika dilihat pada Gambar 3 maka besar sudut shoulder yang ditandakan dengan $\theta_{1}$ yang artinya $\theta_{1}=\beta+\alpha$ dapat diseleaikan seperti Persamaan (16).

$$
\begin{gathered}
\beta=\sin ^{-1}\left(\frac{l_{2} \sin \left(\theta_{2}\right)}{\sqrt{x^{2}+y^{2}}}\right) \\
\theta_{1}=\sin ^{-1}\left(\frac{l_{2} \sin \left(\theta_{2}\right)}{\sqrt{x^{2}+y^{2}}}+\tan ^{-1}\left(\frac{y}{x}\right)\right)
\end{gathered}
$$

Dengan Persamaan (16) besar sudut shoulder dapat diketahui dengan memasukkan nilai panjang elbow, sudut elbow, dan juga posisi koordinat $x, y$ dari posisi end-efffector.

\subsection{Sistem Keseluruhan}

Perancangan sistem keseluruhan merupakan gabungan dari perancangan perangkat keras dan perangkat lunak yang diintegrasikan sesuai dengan blok diagram sistem. Perangkat keras pada sistem terdiri dari dari segi mekanis dan segi elektronis. Sedangkan perangkat lunak merupakan perancangan antarmuka untuk mengendalikan robot SCARA Serpent secara keseluhan. Gambar 4 merupakan rancangan sistem secara keseluruhan.

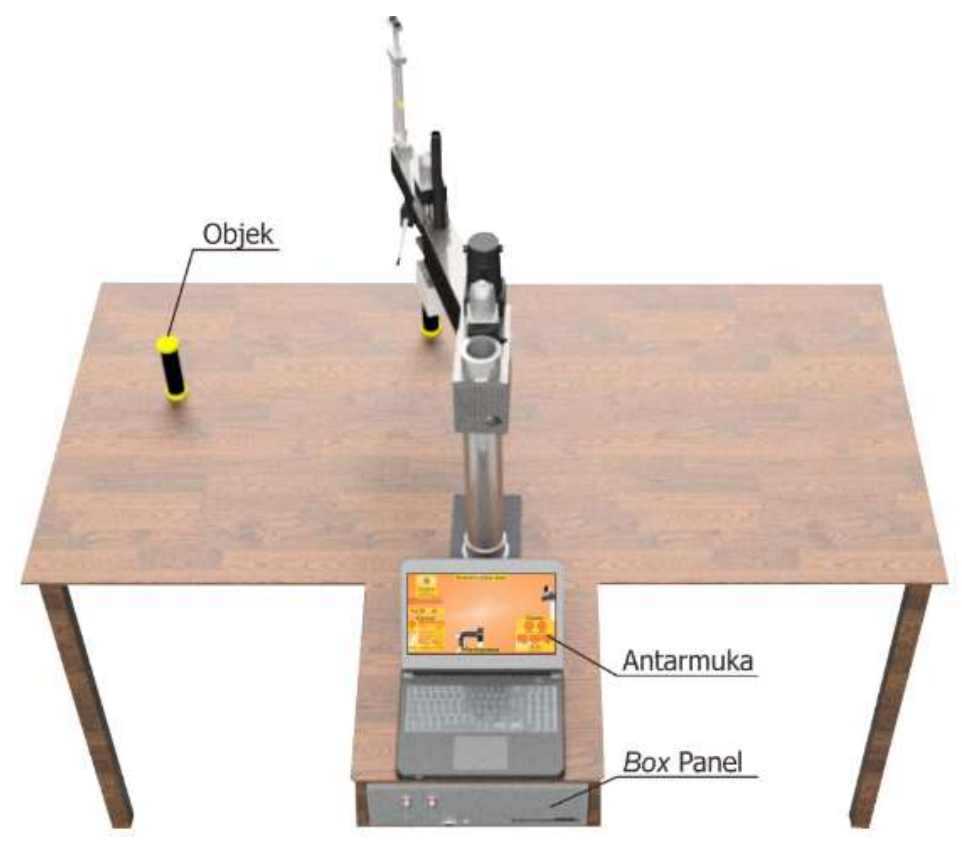

Gambar 4. Perancangan Sistem Keseluruhan Robot SCARA Serpent

Robot SCARA Serpent yang digunakan pada penelitian ini memiliki lengan sholder, elbow, dan satu buah end-effectoryang menggunakan pneumatic sebagai penggeraknya. Jika dilihat pada 
Gambar 4, sistem keseluruhan terdapat tiga komponen utama untuk mendukung kinerja dari sistem. Komponen tersebut yaitu, objek, antarmuka, dan box panel. Objek merupakan target dari robot SCARA Serpent yang memiliki tinggi $150 \mathrm{~mm}$ dan berdiameter $50 \mathrm{~mm}$. Objek ini ditempatkan pada koordinat tertentu dan robot SCARA Serpent akan menuju posisi tersebut dengan antarmuka Processing IDE sebagai pemberi nilai koordinatnya. Antarmuka berfungsi sebagai pengendali dari robot SCARA Serpent seperti memberikan nilai koordinat dari objek dan melakukan perhitungan kinematika untuk mendapatkan nilai sudut setiap joint. Gambar 5 merupakan antarmuka dari Robot SCARA Serpent.

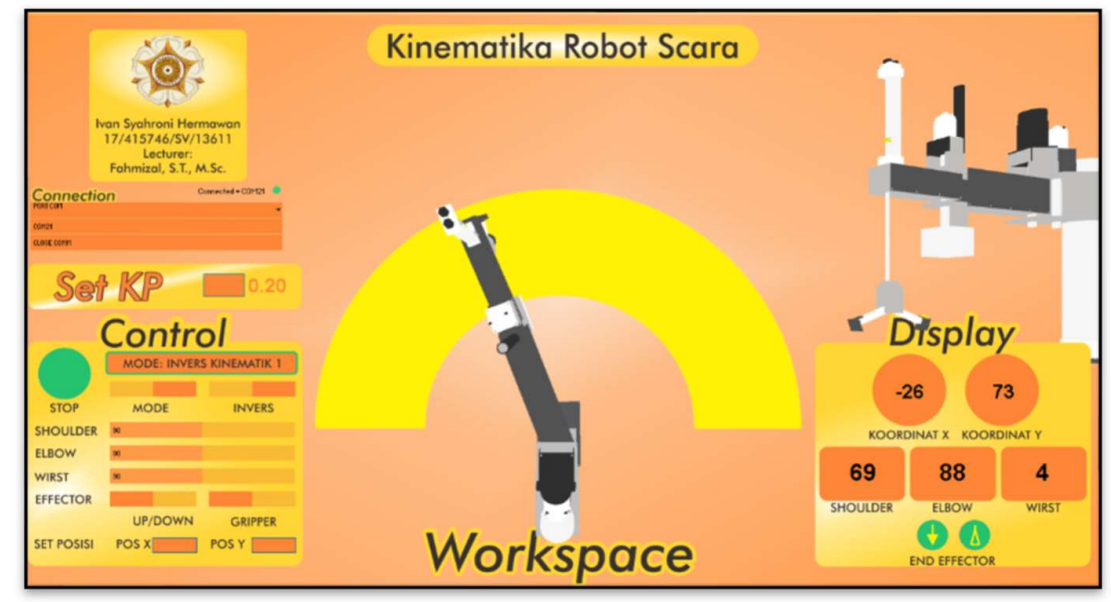

\section{Gambar 5. Antarmuka Robot SCARA Serpent}

Boxpanel berfungsi sebagai tempat dari keseluruhan sistem elektronis. Sistem elektronis pada robot SCARA Serpent terdiri dari PCB utama, transformator, driver motor serta valve pneumatic. Gambaran dari sistem elektronis pada robot SCARA Serpent ditunjukkan pada Gambar 6.

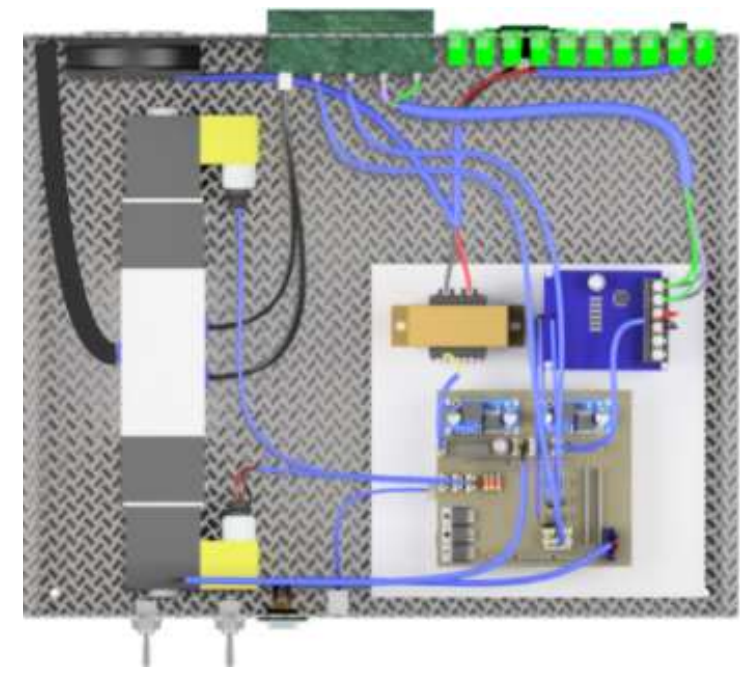

(a)

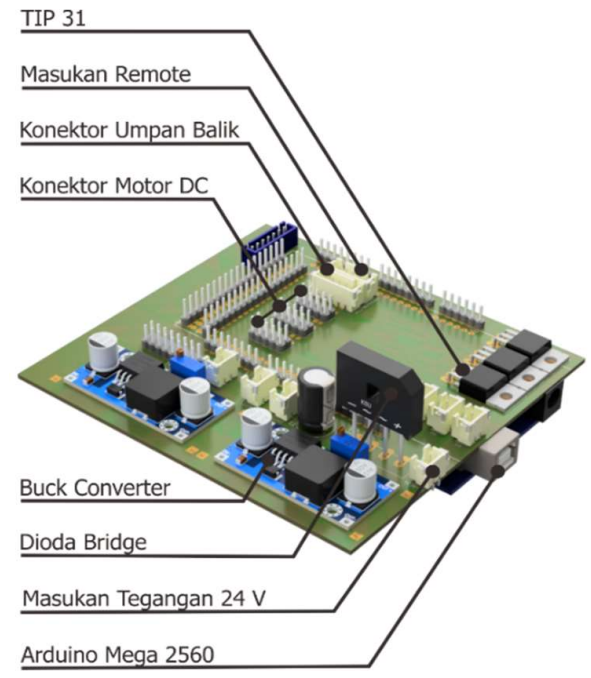

(b)

Gambar 6. (a) Sistem Elektronis Robot SCARA Serpent; (b) Desain PCB Sistem Utama 


\section{PENGUJIAN DAN PEMBAHASAN}

Pengujian yang dilakukan terdiri dari pengujian sub-sistem dan pengujian sistem terintegrasi. Pengujian sub-sistem meliputi pengujian sudut shoulder, sudut elbow, koordinat $x$ dan $y$. Sedangkan pengujian sistem terintegrasi meliputi pengujian kendali PID.

\subsection{Pengujian Sub-Sistem}

Pengujian sub-sistem dilakukan untuk melihat respon dan karakteristik sensor dan respon pada setiap lengan robot SCARA Serpent. Respon yang dihasilkan dari setiap pengujian kemudian dibandingkan dengan nilai yang terukur untuk menentukan akurasi dan nilai kesalahan pada setiap sudut joint.

\subsubsection{Pengujian Sudut}

Pengujian sudut bertujuan untuk mengetahui tingkat akurasi pada masing-masing joint. Pengujian dilakukan dengan memberikan nilai pada masing-masing joint yang kemudian diukur secara aktual. Perbedaan nilai dari yang terukur dengan yang ditentukan merupakan nilai kesalahan yang dihasilkan. Gambar 7 merupakan hasil pengujian dari sudut shoulder dan elbow.

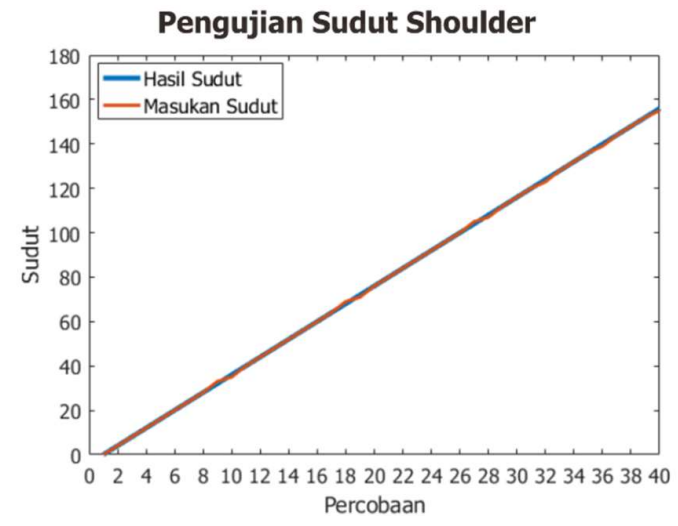

(a)

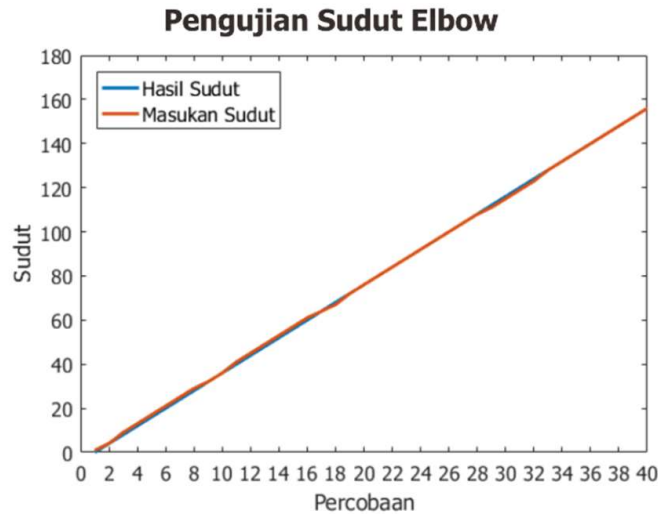

(b)

\section{Gambar 7. (a) Pengujian Sudut Shoulder; (b) Pengujian Sudut Elbow}

Hasil dari pengujian sudut yang ditunjukkan pada Gambar 7 menunjukkan beberapa perbedaan nilai pada beberapa kondisi. Hal ini merupakan besar nilai kesalahan yang dihasilkan pada masing-masing joint. Terlihat bahwa pengujian joint shoulder mendapatkan hasil yang cukup baik dengan ditandai oleh nilai terukur yang tidak menyimpang dari nilai yang diberikan. Begitu juga dengan joint elbow yang terlihat bahwa nilai terukur tidak menyimpang dengan nilai yang dimasukkan. Dengan hasil kedua pengujian tersebut, pengujian sudut dapat dikatakan berjalan dengan baik karena tingkat kesalahan yang dihasilkan tidak melebihi batas toleransi.

\subsubsection{Pengujian Koordinat}

Pengujian koordinat bertujuan untuk mengetahui tingkat akurasi pada end-effetor dalam mencapai sebuah posisi. Pada pengujian ini, penggunaan kinematika balik sangat berperan karena pengujian dilakukan dengan cara memberikan sebuah nilai koordinat $(x, y)$ kepada robot SCARA Serpent. Koordinat tersebut di dalam Processing IDE dilakukan sebuah proses perhitungan kinematika balik sehingga pergerakan pada masing-masing lengan dapat 
membuat end-effector menuju pada posisi yang diberikan. Gambar 8 merupakan hasil pengujian koordinat $x$ dan koordinat $y$ dari robot SCARA Serpent.

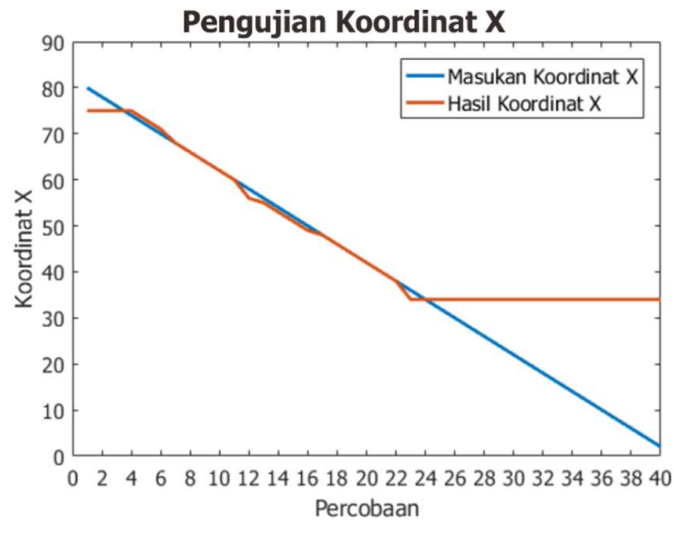

(a)

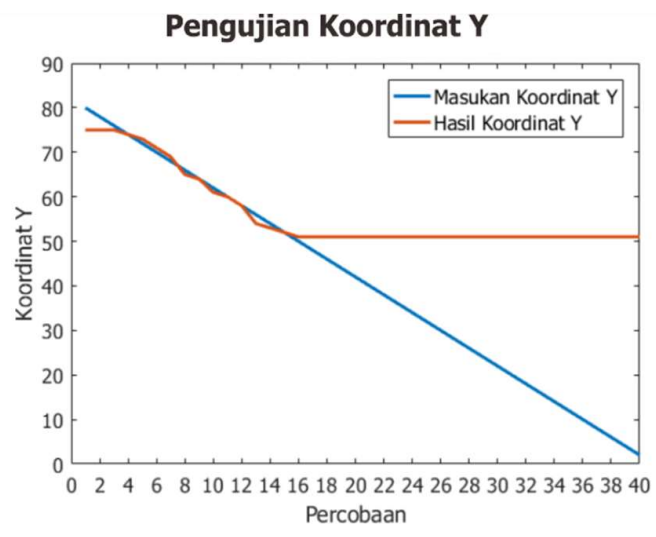

(b)

Gambar 8. (a) Pengujian Koordinat $x$ (b) Pengujian Koordinat $y$

Dari pengujian koordinat yang telah ditunjukkan pada Gambar 8, terlihat bahwa pada saat telah mencapai nilai tertentu, nilai yang terukur menujukkan hasil yang sangat menyimpang. Pada pengujian koordinat $x$ ketika nilai yang diberikan kurang dari $34 \mathrm{~cm}$, nilai $x$ yang terukur tetap berada pada posisi $34 \mathrm{~cm}$. Hal ini disebabkan karena terbatasnya pergerakan yang dimiliki setiap lengan dari robot SCARA Serpent sehingga posisi tersebut tidak dapat dicapai oleh end-effector. Begitu juga dengan pengujian koordinat $y$, pada koordinat $y$ robot hanya dapat mencapai nilai pada posisi $51 \mathrm{~cm}$ hingga $75 \mathrm{~cm}$. Batas dari pengujian koordinat $x$ dan $y$ dapat dijadikan sebuah workspace dari robot SCARA Serpent yang dapat digambarkan seperti Gambar 9.

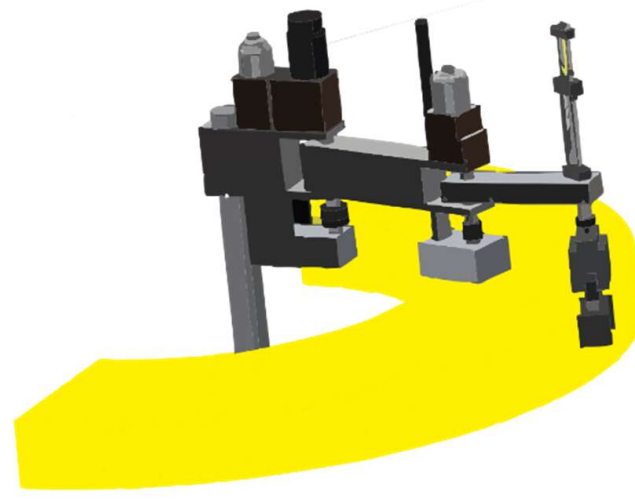

(a)

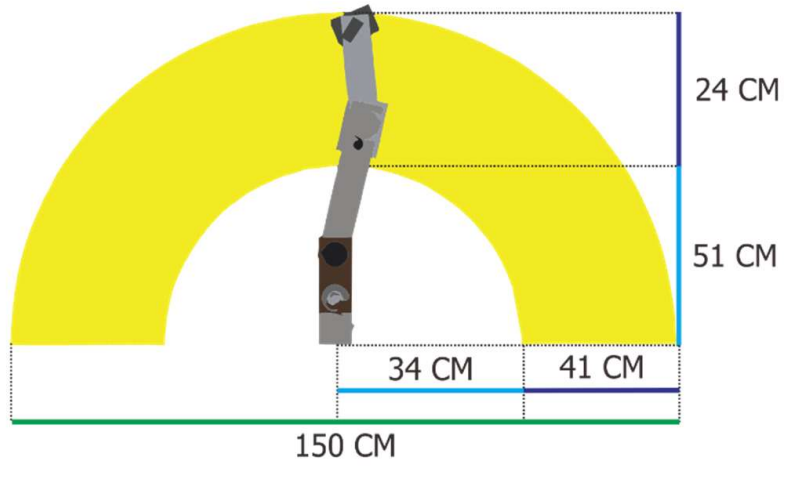

(b)

\section{Gambar 9. (a) Workspace Robot SCARA Serpent; (b) Dimensi Workspace Robot SCARA Serpent}

\subsection{Pengujian Kendali PID}

Kendali PID digital merupakan bentuk lain dari kendali PID yang diprogram dan dijalankan menggunakan komputer atau mikrokontroler. Untuk dapat mengimplementasikan PID digital di komputer atau mikrokontroler, maka kendali PID analog harus diubah terlebih dahulu ke bentuk digital. Penurunan kendai PID digital dapat dilihat pada Persamaan (17)-(19). Bentuk 
persamaan matematis dari kendali PID disajikan pada Persamaan (17) (Ogata \& Yang, 2010).

$$
u(t)=K_{P} e(t)+\frac{1}{\tau_{i}} \int e(t) d t+\tau_{d} \frac{d}{d t} e(t)
$$

Dengan $K_{i}=\frac{1}{\tau_{i}}$ dan $K_{d}=\tau_{d}$, bentuk integral dan diferensial dapat ditulis dalam bentuk diskrit seperti pada Persamaan (18). Sehingga diperoleh dalam bentuk kendali PID diskrit pada Persamaan (19).

$$
\begin{aligned}
& \int_{0}^{t} e(t) \mathrm{dt} \approx \mathrm{T} \sum_{0}^{k} e(k) \mathrm{dan} \frac{\mathrm{de}(t)}{\mathrm{dt}} \approx \frac{e_{k}-e_{k-1}}{T} \\
& u_{(k)}=K_{p} e_{k}+K_{i} T \sum_{0}^{k} e_{k}+\frac{1}{T} K_{d}\left(e_{k}-e_{k-1}\right)
\end{aligned}
$$

Dimana $K_{p}$ ialah konstanta proportional, $K_{i}$ ialah konstanta integral, $K_{d}$ ialah konstanta diferensial, error ialah nilai kesalahan, dan last_error ialah nilai kesalahan sebelumnya serta Ts ialah sampling time (waktu cuplik).

Pengujian Kendali PID dilakukan untuk mengetahui kinerja pengendali PID ketika diimplementasikan pada sebuah robot lengan SCARA Serpent. Pada pengujian ini diamati tiga buah nilai parameter kendali PID yang akan diberikan untuk mengendalikan posisi sudut joint shoulder. Tujuan pengujian ini untuk mendapatkan hasil terbaik yang ditunjukkan dengan pengamatan waktu yang diperlukan untuk mencapai posisi tertentu menuju setpointatau error steady state menuju nol. Pengujian ini dilakukan dengan cara memberikan nilai $K_{p}, K_{i}$, dan $K_{d}$ kepada sistem secara ekperimental dan melihat respon yang diberikan oleh robot SCARA Serpent. Terdapat lima jenis variasi parameter kendali PID yang diterapkan. Tabel 3 merupakan hasil pengujian dari kendali PID pada sudut joint shoulder.

Tabel 3. Pengujian Kendali PID Sudut Joint Shoulder

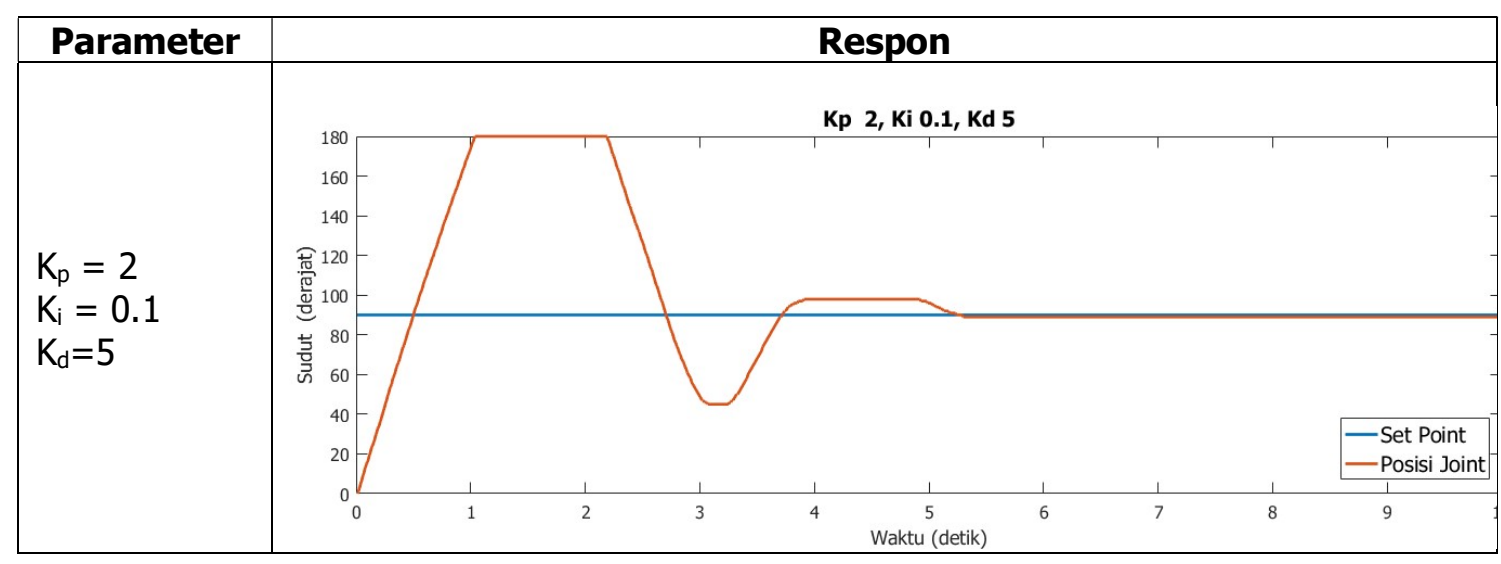


Tabel 3. Pengujian Kendali PID Sudut Joint Shoulder(Lanjutan)

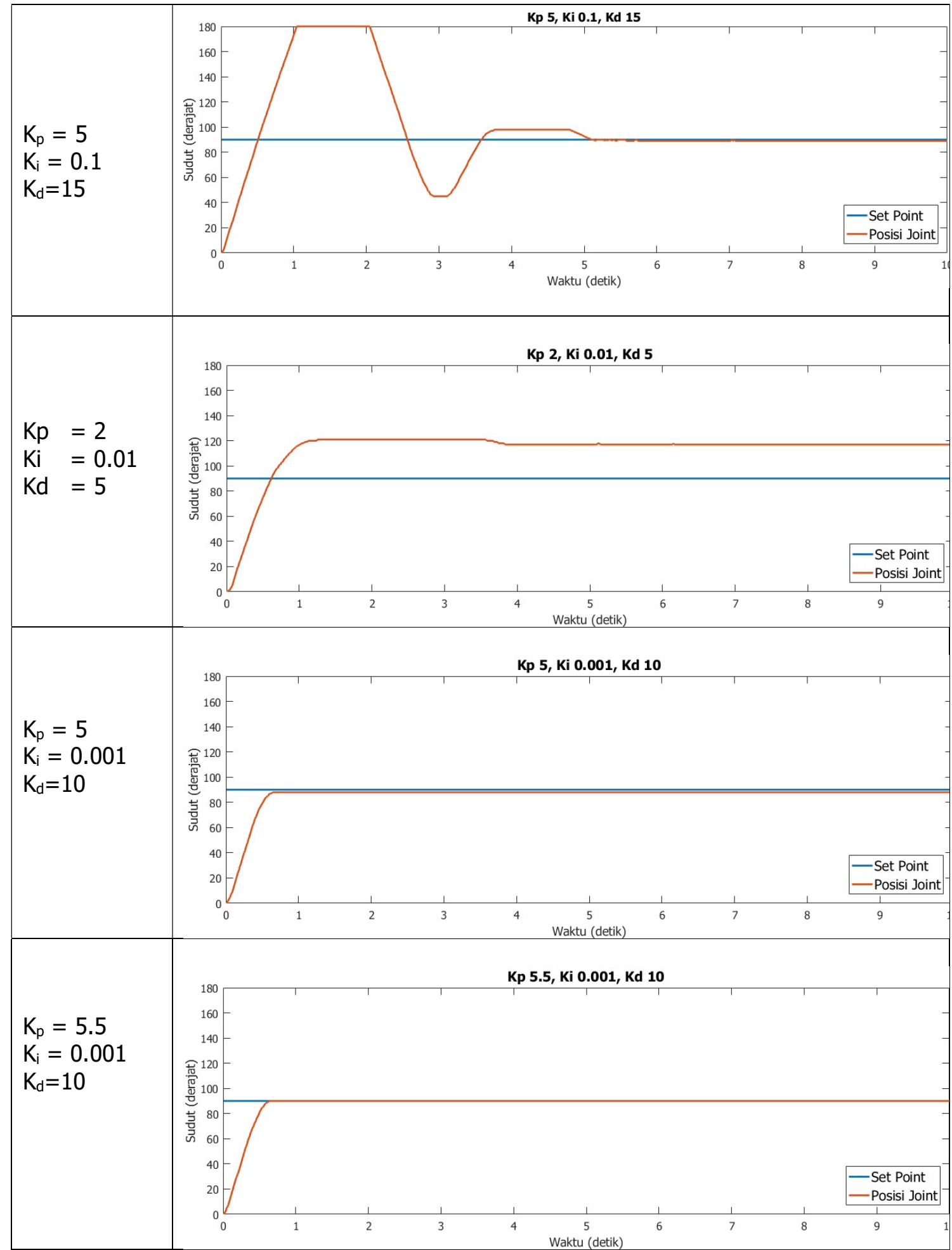

Dari hasil pengujian kendali PID seperti yang ditunjukkan pada Tabel 3, terlihat bahwa respon yang dihasilkan oleh sudut joint shouldermenunjukkan respon yang berbeda-beda. Perbedaan 
pada setiap respon dipengaruhi oleh tiga parameter yang diberikan kepada sistem. Setiap nilai parameter yang diberikan memberikan efek terhadap respon dari sudut joint shoulder. Pada percobaan kendali PID dengan nilai $\mathrm{K}_{\mathrm{p}}=2, \mathrm{~K}_{\mathrm{i}}=0.1$, dan $\mathrm{K}_{\mathrm{d}}=5$ terlihat bahwa respon sudut joint shouldermenghasilkan bentuk bergelombang dengan nilai terukur 20 hingga 180 derajat. Nilai ini disebabkan oleh kurang tepatnya pemberian nilai parameter kendali PID ke dalam sistem sehingga menghasilkan respon yang memiliki osilasi. Respon ini kurang baik. Nilai yang baik pada percobaan ditunjukkan pada respon dengan nilai $\mathrm{K}_{\mathrm{p}}=5.5, \mathrm{~K}_{\mathrm{i}}=0.001$, dan $\mathrm{K}_{\mathrm{d}}=10$ karena pada respon tersebut menunjukkan sudut joint shoulder dapat mencapai posisi secara cepat dan berhenti tepat sesuai dengan set point yang diberikan dan kemudian tidak mengalami osilasi dalam arti lain error steady state bernilai nol.

\section{KESIMPULAN}

Makalah ini menyajikan pembahasan terkait kinematika dan antarmuka berbasis Processing IDE pada robot lengan SCARA Serpent. Untuk membuat pergerakan sudut joint pada robot lengan SCARA Serpent bergerak stabil dan membuat posisi dari end-effector dari robot SCARA Serpent menjadi lebih cepat dan tepat saat menuju titik yang telah ditentukan maka kendali PID diterapkan. Pada hasil pengujian kendali PID menunjukkan bahwa dengan nilai $\mathrm{K}_{\mathrm{p}}=5.5$, $\mathrm{K}_{\mathrm{i}}=0.001$, dan $\mathrm{K}_{\mathrm{d}}=10$ membuat pergerakan sudut joint shoulder robot SCARA Serpent menjadi lebih baik dalam hal pencapaian posisi, akurasi, dan kestabilan saat melakukan sebuah pergerakan.

\section{UCAPAN TERIMA KASIH}

Penulis mengucapkan terima kasih kepada Program Studi S2 Pendidikan IPA FKIP, Universitas Bengkulu dengan Departemen Teknik Elektro dan Informatika Sekolah Vokasi Universitas Gadjah Mada atas dukungan yang telah diberikan kepada penulis untuk melakukan kolaborasi riset antar universitas.

\section{DAFTAR RUJUKAN}

Bimantaka, B. N. W., \& Harjoko, A. (2014). Purwarupa Robot Lengan Pemilah Objek Berdasarkan Label Tulisan Secara Realtime. IJEIS (Indonesian Journal of Electronics and Instrumentation Systems), 4(2), 135-146.

Dharmawan, A. B., \& Lina, L. (2017). Penerapan Metode Denavit-Hartenberg Pada Perhitungan Inverse Kinematics Gerakan Lengan Robot. Jurnal Muara Sains, Teknologi, Kedokteran dan IImu Kesehatan, 1(1), 287-292.

Faris, M. F., Triwiyatno, A., \& Setiawan, I. (2012). Perancangan Arm Manipulator 4 DOF Dengan Menggunakan Pengendalian Cartesian Space-Trajectory Planning. Transient: Jurnal IImiah Teknik Elektro, 1(4), 151-158.

Fazakerley, N. (2018). Serpent - a SCARA robot arm. Diakses dari Beep Control: http://www.riscy.uk/beebcontrol/index.html. 
Mandal, D. K. (2016). CAD/CAM, Robotics and Factories of the Future. Proceedings of the 28th International Conference on CARs \& Fof 2016 (pp. 128-133). India: Springer India.

Ogata, K., \& Yang, Y. (2010). Modern control engineering (Vol. 5). Upper Saddle River, NJ: Prentice hall.

Oktama, R., Maulana, R., \& Setyawan, G. E. (2018). Implementasi Robot Lengan Pemindah Barang 3 DOF Menggunakan Metode Inverse Kinematics. Jurnal Pengembangan Teknologi Informasi Dan IImu Komputer, 2811-2812.

Pillajo, C., \& Sierra, J. E. (2013). Human Machine Interface HMI using Kinect sensor to control a SCARA Robot. In 2013 IEEE Colombian Conference on Communications and Computing (COLCOM), (pp. 1-5). IEEE.

Prabantara, S. H., \& Harjoko, A. (2013). Analisis Kinematika Balik pada Kendali Robot Lengan Dental Light Berbasis Pengolahan Citra Digital Berdasarkan Isyarat Tangan. IJEIS (Indonesian Journal of Electronics and Instrumentation Systems), 3(2), 207-218.

Setiawan, S., Firdaus, F., Rahmadya, B., \& Derisma, D. (2015). Penerapan Invers Kinematika untuk Pergerakan Kaki Robot Biped. Prosiding Semnastek.

Shariatee, M., Akbarzadeh, A., Mousavi, A., \& Alimardani, S. (2014, October). Design of an economical SCARA robot for industrial applications. In 2014 Second RSI/ISM International Conference on Robotics and Mechatronics (ICRoM), (pp. 534-539). IEEE.

Uchrowi, A. Z., Lasmadi, L., \& Soekarno, S. (2019). Pemodelan dan Simulasi Robot Lengan 3 DOF Menggunakan V-REP. Aviation Electronics, Information Technology, Telecommunications, Electricals, and Controls, 1(1), 87-98.

Vijayalaxmi, P., Putta, R., Shinde, G., \& Lohani, P. (2013). Object Detection Using Image Processing for an Industrial Robot. International Journal of Advanced Computational Engineering and Networking, 21-25.

Zhang, C., \& Zhang, Z. (2019, October). Modelling and Simulation of SCARA Robot using MATLAB/SimMechanics. In 2019 IEEE 3rd Advanced Information Management, Communicates, Electronic and Automation Control Conference (IMCEC) (pp. 516-519). IEEE. 